University of Nebraska - Lincoln

DigitalCommons@University of Nebraska - Lincoln

1996

\title{
Effect of nitrate, organic carbon, and temperature on potential denitrification rates in nitrate-rich riverbed sediments
}

\author{
K. S. Pfenning \\ U.S. Geological Survey \\ P. B. McMahon \\ U.S. Geological Survey, pmcmahon@usgs.gov
}

Follow this and additional works at: https://digitalcommons.unl.edu/usgsstaffpub

Part of the Earth Sciences Commons

Pfenning, K. S. and McMahon, P. B., "Effect of nitrate, organic carbon, and temperature on potential denitrification rates in nitrate-rich riverbed sediments" (1996). USGS Staff -- Published Research. 438. https://digitalcommons.unl.edu/usgsstaffpub/438

This Article is brought to you for free and open access by the US Geological Survey at DigitalCommons@University of Nebraska - Lincoln. It has been accepted for inclusion in USGS Staff -- Published Research by an authorized administrator of DigitalCommons@University of Nebraska - Lincoln. 


\title{
Effect of nitrate, organic carbon, and temperature on potential denitrification rates in nitrate-rich riverbed sediments
}

\author{
K.S. Pfenning*, P.B. McMahon
}

US Geological Survey, Denver Federal Center, Mail Stop 415, Denver, CO 80255, USA

Received 7 November 1995; revised 13 February 1996; accepted 15 February 1996

\begin{abstract}
A study conducted in 1994 as part of the US Geological Survey's National Water-Quality Assessment Program, South Platte River Basin investigation, examined the effect of certain environmental factors on potential denitrification rates in nitrate-rich riverbed sediments. The acetylene block technique was used to measure nitrous oxide $\left(\mathrm{N}_{2} \mathrm{O}\right)$ production rates in laboratory incubations of riverbed sediments to evaluate the effect of varying nitrate concentrations, organic carbon concentrations and type, and water temperature on potential denitrification rates. Sediment incubations amended with nitrate, at concentrations ranging from 357 to $2142 \mu \mathrm{mol} \mathrm{l}{ }^{-1}$ (as measured in the field), produced no significant increase $(P>0.05)$ in $\mathrm{N}_{2} \mathrm{O}$ production rates, indicating that the denitrification potential in these sediments was not nitrate limited. In contrast, incubations amended with acetate as a source of organic carbon, at concentrations ranging from 0 to $624 \mu \mathrm{mol} \mathrm{l}{ }^{-1}$, produced significant increases $(P<0.05)$ in $\mathrm{N}_{2} \mathrm{O}$ production rates with increased organic carbon concentration, indicating that the denitrification potential in these sediments was organic carbon limited. Furthermore, $\mathrm{N}_{2} \mathrm{O}$ production rates also were affected by the type of organic carbon available as an electron donor. Acetate and surface-water-derived fulvic acid supported higher $\mathrm{N}_{2} \mathrm{O}$ production rates than groundwater-derived fulvic acid or sedimentary organic carbon. Lowering incubation temperatures from 22 to $4^{\circ} \mathrm{C}$ resulted in about a $77 \%$ decrease in the $\mathrm{N}_{2} \mathrm{O}$ production rates. These results help to explain findings from previous studies indicating that only $15-30 \%$ of nitrate in groundwater was denitrified before discharging to the South Platte River and that nitrate concentrations in the river generally were higher in winter than in summer.
\end{abstract}

\section{Introduction}

The US Environmental Protection Agency has set the maximum contaminant level (MCL) for nitrate in drinking water at $10 \mathrm{mg} \mathrm{l}^{-1}$ as nitrogen $\left(714 \mu \mathrm{mol} \mathrm{l}^{-1}\right)$. Groundwater

\footnotetext{
- Corresponding author.
} 


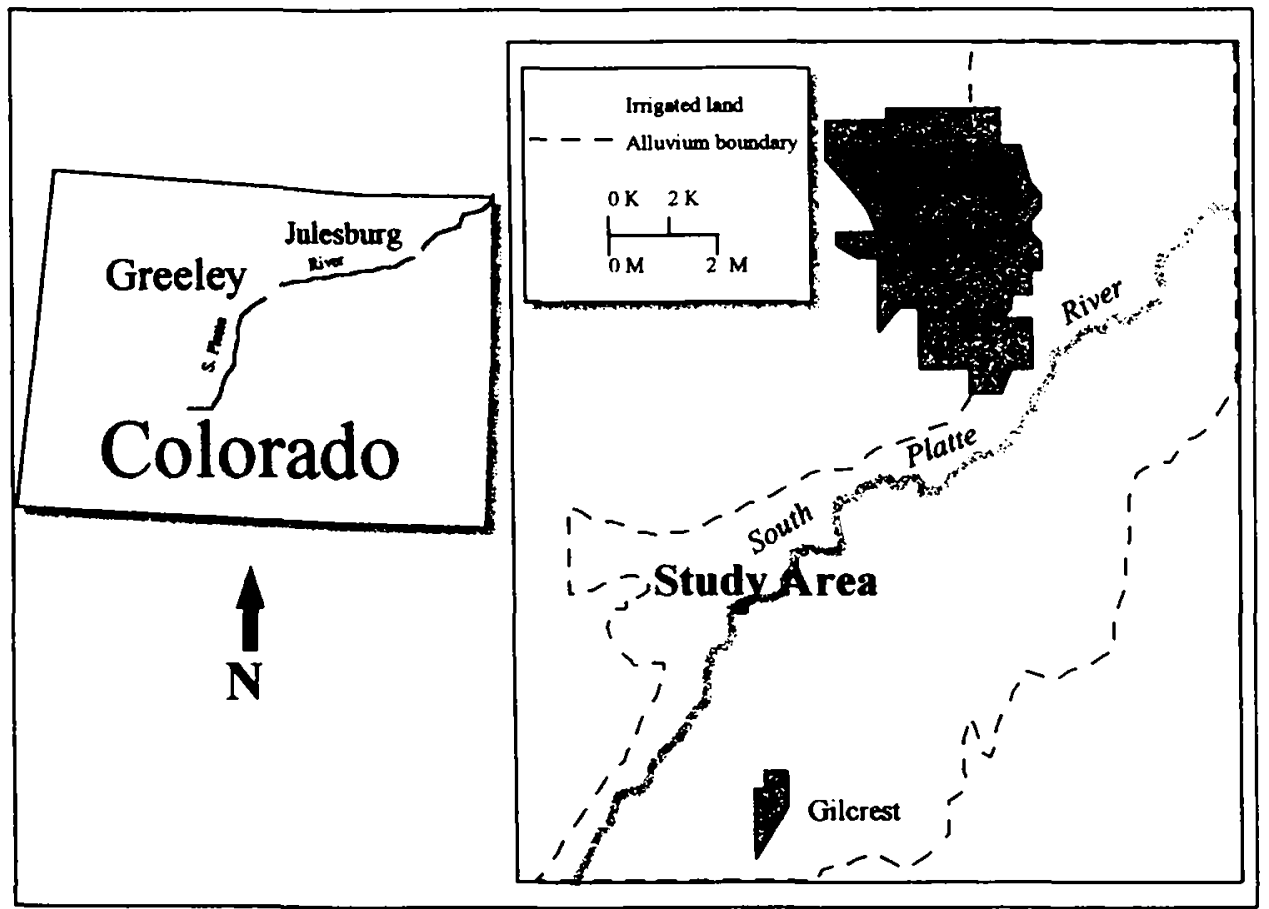

Fig. 1. Location of study area.

in agricultural areas often contains nitrate in excess of the MCL owing to anthropogenic sources such as fertilizers, septic tank drainage, feedlots, and dairy and poultry farming (Madison and Brunett, 1984; Gold et al., 1990; Bouchard et al., 1992). At concentrations above the MCL, nitrate can be toxic to infants and pose other human health problems (Bouchard et al., 1992). In addition, nitrate-contaminated groundwater discharging to surface water can degrade water quality by promoting eutrophication of surface water.

A buildup of nitrate in the groundwater of the South Platte alluvial aquifer in Colorado has occurred because of application of nitrogen to fields and leaching of nitrogen by irrigation water (Austin, 1993; Wylie et al., 1993; McMahon and Böhlke, 1996) (Fig. 1). In these areas of irrigated agriculture, discharge from the aquifer is a major contributor to flow in the South Platte River (Robson, 1989). Measured rates of groundwater discharge ranged from 0.097 to as high as $0.198 \mathrm{~m}^{3} \mathrm{~s}^{-1} \mathrm{~km}^{-1}$ during the irrigation season (Ruddy, 1984). When substantial quantities of groundwater having elevated nitrate concentrations discharged to the river, nitrate concentrations in the river increased (McMahon and Böhlke, 1996). Earlier studies indicated that denitrification in sediments underlying and adjacent to the river removed a part of the nitrate from groundwater before its discharge to the river (McMahon and Böhlke, 1996). However, those studies did not identify the factors affecting denitrification, such as nitrate concentration, organic carbon availability, and temperature (Smith and Duff, 1988; Morris et al., 1988; Fujikawa and Hendry, 1991; Smith et al., 1991; Korom, 1992; Starr and Gillham, 1992; Bradley et al., 1992, 1995; Hanson et al., 1994). 
In 1994, as part of the US Geological Survey National Water-Quality Assessment (NAWQA) program, South Platte River Basin investigation, a study was conducted to examine the effect of several environmental factors on denitrification rates. This paper presents the results of that investigation, in which the effects of varying nitrate concentrations, organic carbon concentrations and type, and water temperature on potential rates of denitrification in riverbed sediments were evaluated.

\section{Study area}

The study area is located in a part of the South Platte River Basin between Gilcrest and Greeley, Colorado (Fig. 1). The alluvial aquifer in this area consists of unconsolidated sand and gravel of Quaternary age with minor amounts of interbedded clay and silt. Relatively impermeable fine-grained sediments of Cretaceous age underlie the aquifer. These Cretaceous sediments yield little water to the aquifer. Irrigation water taken from the South Platte River and from the alluvial aquifer is applied to fields overlying the alluvium and provides the main source of recharge for the aquifer. The aquifer in the study area has a saturated thickness of about $10-20 \mathrm{~m}$. Groundwater in the study area generally flows to the west-northwest toward the river. The South Platte River at the study area is moderately braided, approximately $50 \mathrm{~m}$ wide, and has an average depth of $0.4 \mathrm{~m}$ (McMahon and Böhlke, 1996).

Groundwater collected from multi-depth piezometers and wells screened below and adjacent to the river in the study area had nitrate concentrations ranging from about 390 to $2000 \mu \mathrm{mol} \mathrm{l}^{-1}$, whereas the nitrate concentrations in the river ranged from 250 to $400 \mu \mathrm{mol} \mathrm{l}^{-1}$ (McMahon and Böhlke, 1996). Concentrations of dissolved organic carbon (DOC) in groundwater ranged from 230 to $310 \mu \mathrm{mol} 1^{-1}$ and one river-water sample contained $433 \mu \mathrm{mol} \mathrm{l}^{-1}$. Measured ground-water temperatures ranged from 2 to $18.1^{\circ} \mathrm{C}$, and river-water temperatures ranged from 4.5 to $21.5^{\circ} \mathrm{C}$. Dissolved oxygen (DO) concentrations in the groundwater from the study area were less than $20 \mu \mathrm{mol} \mathrm{l}^{-1}$. The nitrate load, based on mass balance, added to the river from groundwater discharge in November 1993 was $230 \mathrm{~kg} \mathrm{~N}$ day $^{-1} \mathrm{~km}^{-1}$ (McMahon and Böhlke, 1996).

\section{Methods}

\subsection{Sediment sampling}

Samples of riverbed sediment were collected from the sediment-water interface (surficial sediments) and from three depths below the interface (buried sediments) to examine the effect of nitrate and organic carbon concentrations on potential denitrification rates in various sediments underlying the river. Riverbed sediment was scooped from the sediment-water interface directly into jars and then refrigerated for as much as 2 weeks until experiment began in the laboratory. Three different surficial sediments were collected based on grain size: fine-, medium-, and coarse-grained sediments (Table 1). Riverbed sediments below the sediment-water interface were extracted, using a peristaltic pump, 
Table 1

Organic carbon content and grain size of sediment sampled

\begin{tabular}{lcc}
\hline Sediment sample & $\begin{array}{l}\text { Sedimentary organic } \\
\text { carbon content (wt \%) }\end{array}$ & $\begin{array}{l}\text { Median grain } \\
\text { size (mm) }\end{array}$ \\
\hline Fine-grained surficial & 0.16 & 0.21 \\
Medium-grained surficial & 0.02 & 0.63 \\
Coarse-grained surficial & 0.02 & 1.20 \\
0.61 m below sediment-water interface & 0.04 & 0.37 \\
1.22 m below sediment-water interface & 0.03 & 0.41 \\
2.44 m below sediment-water interface & 0.01 & 0.37 \\
\hline
\end{tabular}

from a drive point with a screen of $15.25 \mathrm{~cm}$ length with openings of $3 \mathrm{~mm}$ diameter. The drive points were hammered into the sediments underlying the river at depths of 0.61 , 1.22 , and $2.44 \mathrm{~m}$ below the sediment-water interface; the drive points were removed after sediment collection. This collection technique excluded any sediment with grain size greater than $3 \mathrm{~mm}$.

\subsection{Solution preparation}

The riverbed sediments were drained to decrease dissolved concentrations of nitrate and organic carbon initially present in the sediment. Once the sediments were drained, varying amounts of nitrate were added to them to analyze the effect of nitrate concentration on potential denitrification rates. Nitrate solutions were made using sodium nitrate and deionized water. The surficial sediments were only incubated in solutions containing $357 \mu \mathrm{mol} \mathrm{l}^{-1}$ nitrate because of the narrow range of nitrate concentrations measured in the river (McMahon and Böhlke, 1996). The buried sediments were incubated in solutions containing 357,1071 or $2142 \mu \mathrm{mol}{ }^{-1}$ nitrate. These concentrations cover the range of nitrate concentrations measured in groundwater at the site.

Solutions containing varying amounts of acetate were added to the sediments in separate experiments to evaluate the extent to which potential denitrification rates were limited by organic carbon availability. All sediments, except for the fine-grained surficial sediments, were incubated with solutions containing 0,208 or $624 \mu \mathrm{mol} l^{-1}$ organic carbon as acetate. The fine-grained surficial sediment was incubated with a solution containing either 0 or $208 \mu \mathrm{mol} \mathrm{Cl} \mathrm{Cl}^{-1}$ as acetate because of its relatively high sedimentary organic carbon content. The initial nitrate concentration was $357 \mu \mathrm{mol} \mathrm{l}^{-1}$ for all incubations used to analyze the effect of organic carbon availability on denitrification rates.

Separate experiments were performed to examine the effect of organic carbon type on potential rates of denitrification by adding $208 \mu \mathrm{mol}^{-1}$ organic carbon as fulvic acid derived from surface water or groundwater (Aiken and Malcolm, 1987) or $208 \mu \mathrm{mol} \mathrm{l}^{-1}$ organic carbon as acetate to the medium-grained surficial sediment. The medium-grained surficial sediment was chosen because of its relatively low sedimentary organic carbon content (Table 1).

All sediments initially were incubated at $22^{\circ} \mathrm{C}$. Additional experiments were run at $4^{\circ} \mathrm{C}$, using the medium-grained surficial sediment to analyze the effect of temperature on 
potential denitrification rates. For these experiments, a solution containing $357 \mu \mathrm{mol} \mathrm{l}^{-1}$ nitrate and either 0 or $208 \mu \mathrm{mol} 1^{-1}$ organic carbon, as acetate, was used.

\subsection{Measuring potential denitrification rates}

Sediments were incubated in $120 \mathrm{ml}$ serum bottles. Each bottle contained $40 \mathrm{~g}$ of moist sediment amended with $50 \mathrm{ml}$ of solution, leaving $55 \mathrm{ml}$ of headspace. To decrease oxygen levels, the sediment and solution then were sparged with oxygen-free nitrogen gas for $5 \mathrm{~min}$ and immediately capped with thick butyl stoppers. To begin incubation, $2.5 \mathrm{ml}$ (5\% of the headspace) of acetylene was injected. The acetylene was generated by adding deionized water to calcium carbide. Acetylene blocks the conversion of $\mathrm{N}_{2} \mathrm{O}$ to $\mathrm{N}_{2}$; studies have indicated that $\mathrm{N}_{2} \mathrm{O}$ production can be used to measure potential denitrification rates (Klemedtsson et al., 1988; Morris et al., 1988; Fujikawa and Hendry, 1991; Bradley et al., 1992). All of the sediment-solution combinations were run in triplicate with a fourth bottle as a control. The control bottles were prepared as the others but were autoclaved for $20 \mathrm{~min}$ at $120^{\circ} \mathrm{C}$ to render denitrifying bacteria inactive before acetylene addition, and thus acted as a baseline for abiotic $\mathrm{N}_{2} \mathrm{O}$ production. The controls did not produce $\mathrm{N}_{2} \mathrm{O}$ during the experiments.

The headspace in the vials was sampled at four or five time steps beginning at time zero. Samples were taken by inserting a $1 \mathrm{ml}$ pressure-lock glass syringe into the butyl stopper and extracting gas from the headspace. Each sample was analyzed for $\mathrm{N}_{2} \mathrm{O}$ and $\mathrm{CO}_{2}$, using a gas chromatograph with a thermal conductivity detector. $\mathrm{N}_{2} \mathrm{O}$ and $\mathrm{CO}_{2}$ concentrations were adjusted for the gas in solution using Bunsen solubility coefficients (Weiss and Price, 1980 ) and Henry's law constants. From these concentrations, the production of $\mathrm{N}_{2} \mathrm{O}$ and $\mathrm{CO}_{2}$ was quantified over time by performing a linear regression on the time-series data. The relation between rates of denitrification and nitrate or organic carbon concentrations was analyzed by linear-regression analysis. Levels of significance were set at $\alpha=0.05$ for all statistical analyses. Once the experiments were completed, sediments were oven-dried before weighing, carbon analysis, and grain-size analysis. Organic carbon was calculated by subtracting inorganic carbon from total carbon, both of which were analyzed using a coulometer.

\section{Results and discussion}

\subsection{Effect of nitrate and organic carbon concentrations on $\mathrm{N}_{2} \mathrm{O}$ production rates}

Rates of $\mathrm{N}_{2} \mathrm{O}$ production did not increase significantly $(P>0.05)$ with increasing nitrate concentration in any buried sediments (Fig. 2). These results indicated that the denitrification potential was not limited by the availability of nitrate, which is consistent with the relatively high concentrations of nitrate measured in groundwater beneath the river at this site (390-2000 $\mu \mathrm{mol} \mathrm{I}^{-1}$; McMahon and Böhlke, 1996)). In contrast, there were significant increases $(P<0.05)$ in $\mathrm{N}_{2} \mathrm{O}$ production rates with increasing acetate concentrations in four of six incubations (Fig. 3). The exceptions-the fine-grained surficial sediment and the 


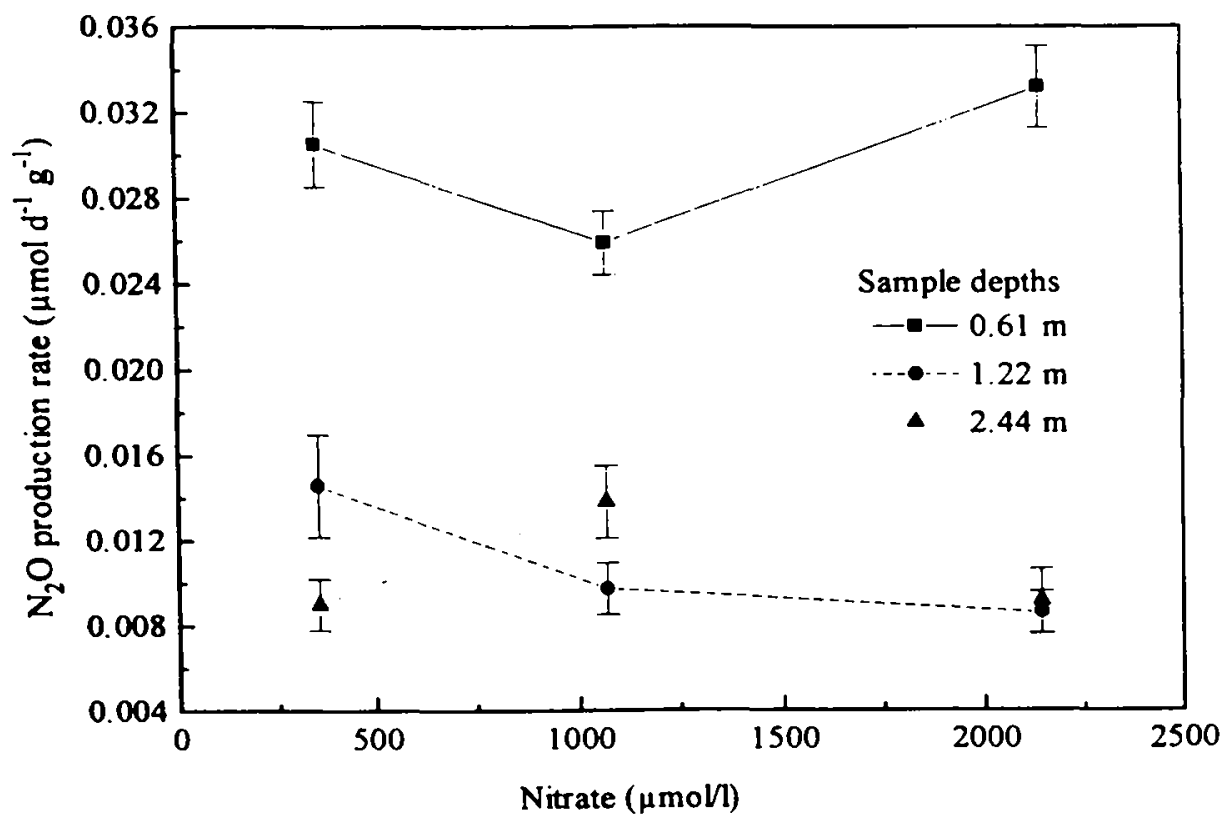

Fig. 2. Relation of $\mathrm{N}_{2} \mathrm{O}$ production rate to nitrate concentration in incubations of buried riverbed sediments. All sediments were incubated without addition of organic carbon. Points represent average of triplicate measurements \pm 1 SD.

buried sediment from the $0.61-\mathrm{m}$ depth did not indicate a significant increase $(P>0.05)$ in $\mathrm{N}_{2} \mathrm{O}$ production rates with increasing acetate concentration. For the fine-grained surficial sediment, the lack of increase was probably due to the relatively high organic carbon content of the sediment (Table 1). Overall, these results indicated that the denitrification potential in most sediments was limited by the availability of organic carbon.

Other studies also have shown that low sedimentary organic carbon contents may limit potential denitrification rates (Smith and Duff, 1988; Morris et al., 1988; Hammon and Fustec, 1991; Starr and Gillham, 1992; Bradley et al., 1992, 1995). A consequence of the organic carbon limitation in the South Platte alluvial aquifer system may be that nitrate in discharging groundwater was only partly denitrified before entering the river. McMahon and Böhlke (1996) estimated that $15-30 \%$ of the nitrate in groundwater at this site was denitrified before discharging to the river. Comparison of potential $\mathrm{N}_{2} \mathrm{O}$ production rates measured under in situ nitrate and organic carbon concentrations with concentrations of nitrate and organic carbon measured in the field (Fig. 4) further supports the conclusion that denitrification potential in the riverbed sediments is generally limited by the availability of organic carbon. The highest potential rates of $\mathrm{N}_{2} \mathrm{O}$ production occurred in surficial sediments containing relatively high organic carbon contents even though stream-water nitrate concentrations were low (Fig. 4). In contrast, lower rates of $\mathrm{N}_{2} \mathrm{O}$ production occurred in buried sediments having less organic carbon, but higher nitrate concentrations. 

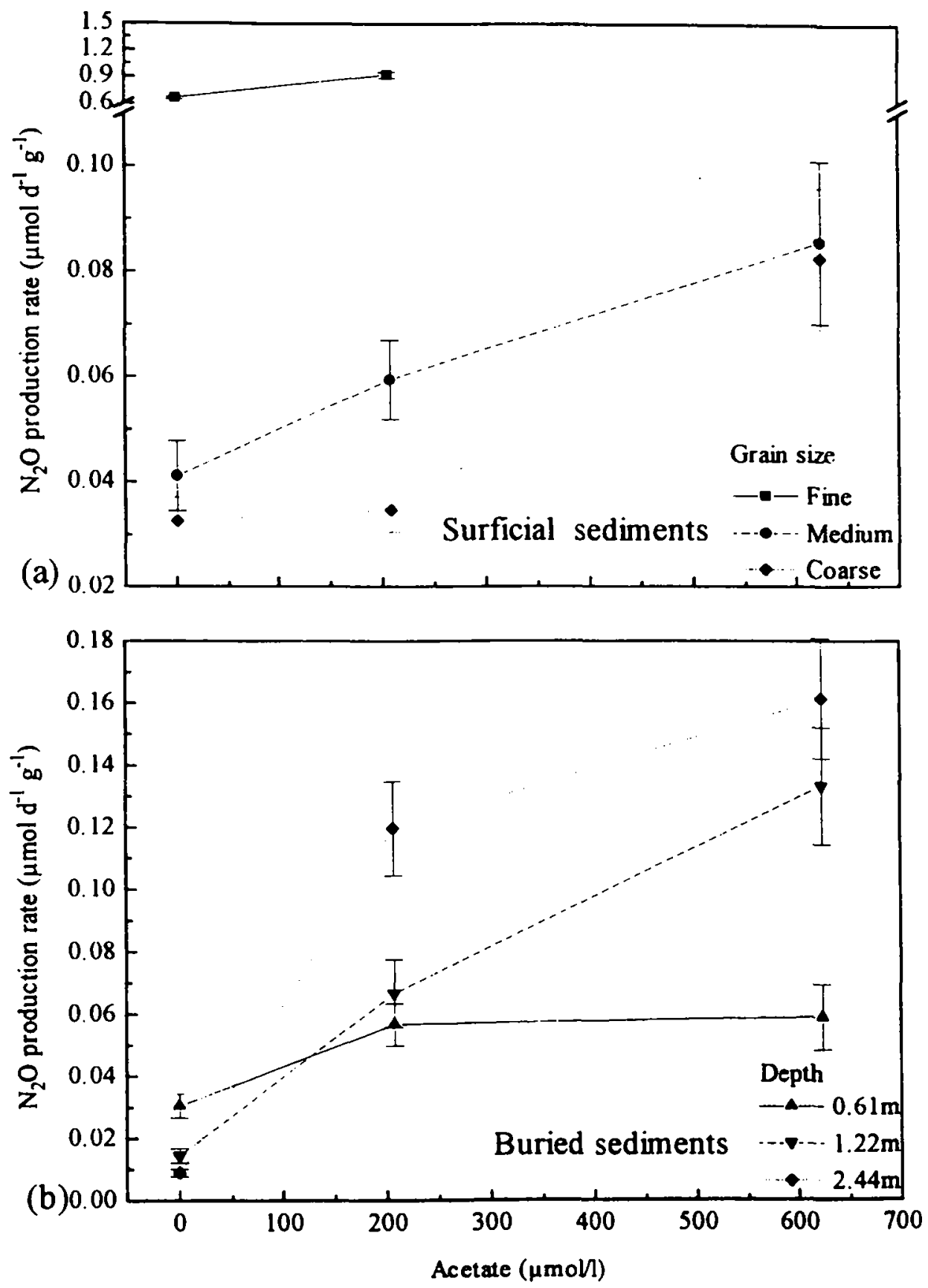

Fig. 3. Relation of $\mathrm{N}_{2} \mathrm{O}$ production rate to acetate concentration (a) for surficial riverbed sediments and (b) for buried riverbed sediments. All sediments were incubated with $357 \mu \mathrm{mol} 1^{-1}$ nitrate. Points represent average of triplicate measurements $\pm 1 \mathrm{SD}$. 

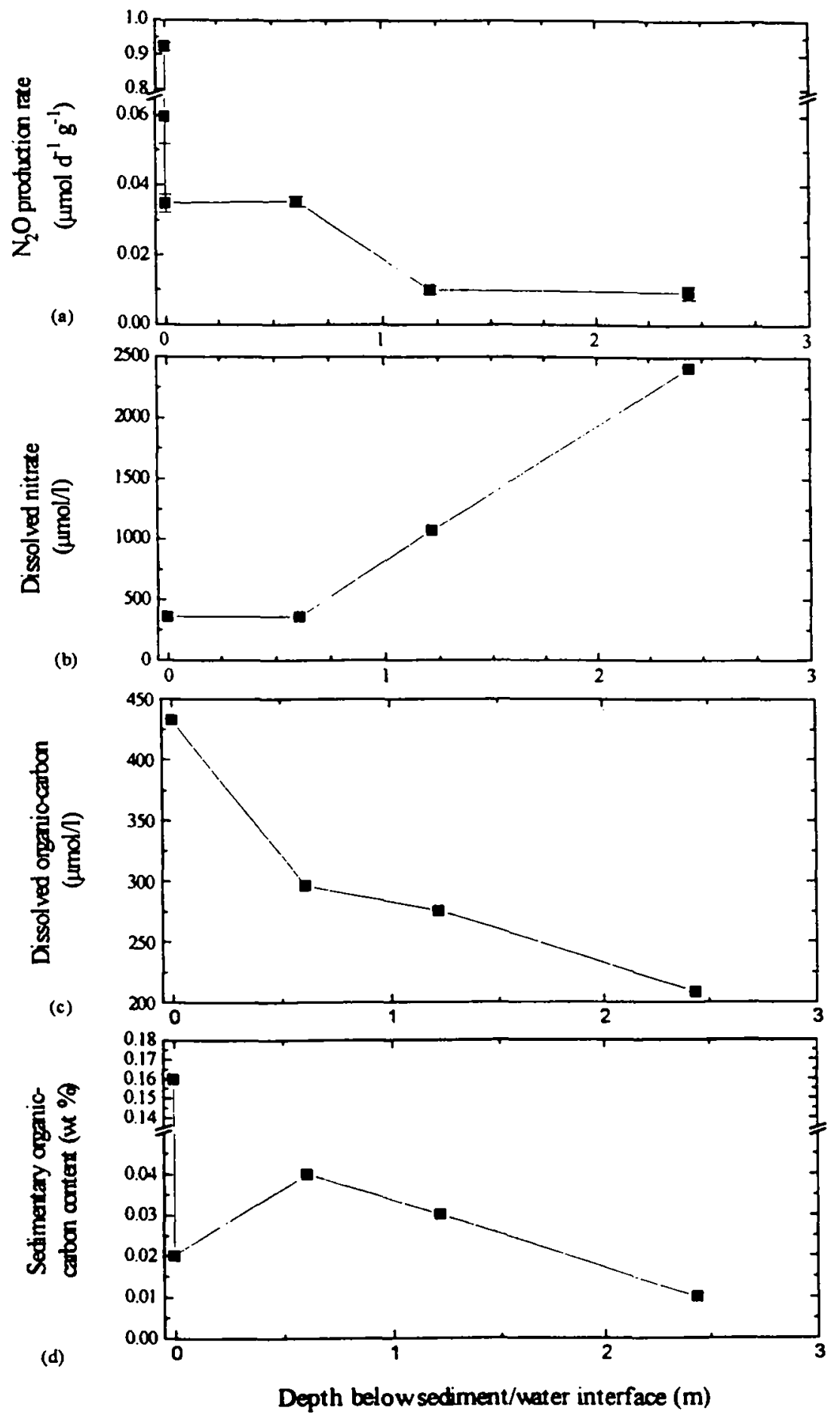


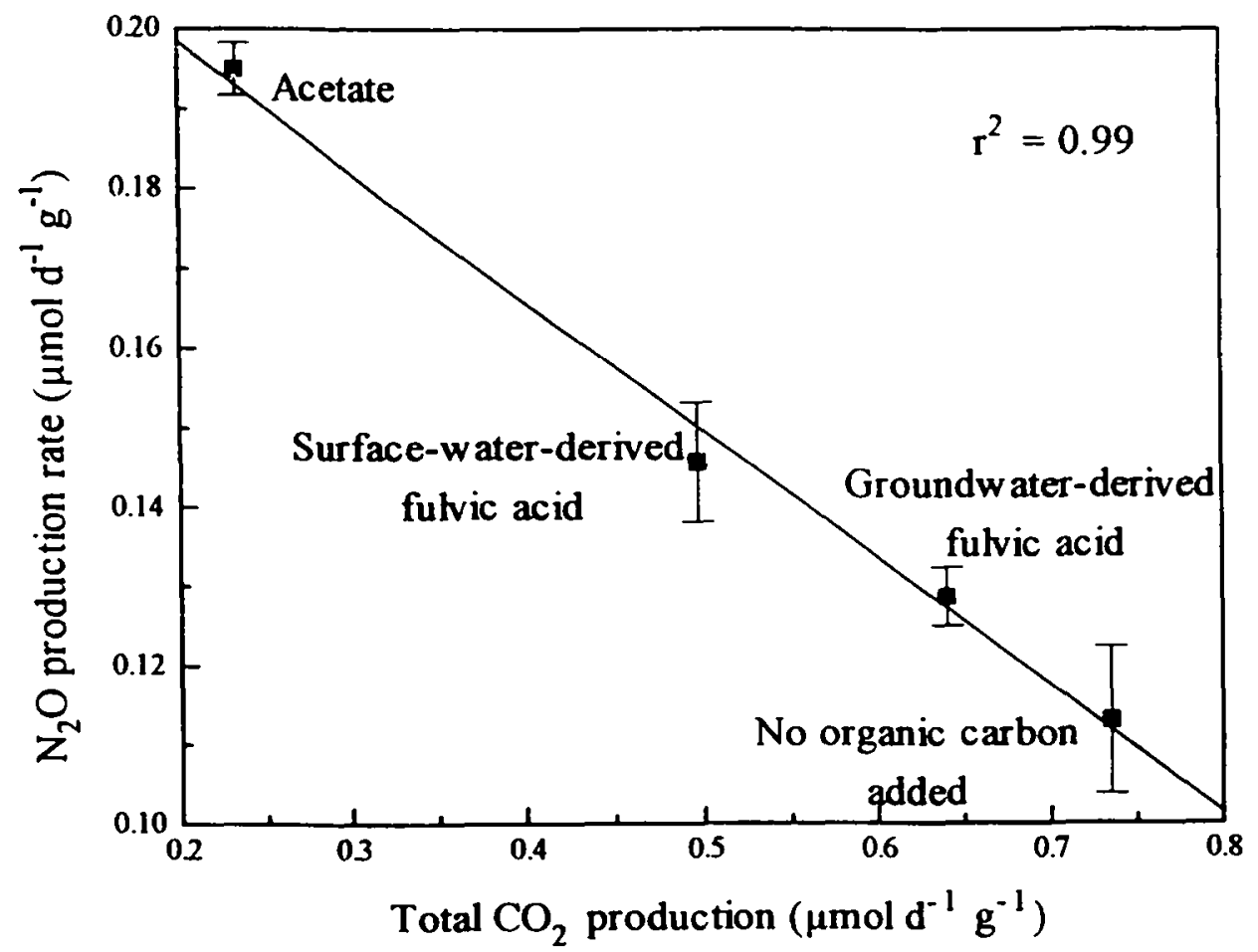

Fig. 5. Relation of $\mathrm{N}_{2} \mathrm{O}$ and total $\mathrm{CO}_{2}$ production rates to types of organic carbon. Medium-grained riverbed sediment was incubated using $208 \mu \mathrm{mol} \mathrm{l}^{-1}$ organic carbon for all incubations, except the incubation having no added organic carbon. Points represent average of triplicate measurements \pm 1 SD.

\subsection{Effect of organic carbon type on $\mathrm{N}_{2} \mathrm{O}$ production rates}

Rates of $\mathrm{N}_{2} \mathrm{O}$ production were related to the type of organic carbon present in the sediments (Fig. 5). The highest $\mathrm{N}_{2} \mathrm{O}$ production rates were in incubations amended with acetate, and the lowest rates were in incubations with no added organic carbon. Rates produced in incubations amended with fulvic acids were intermediate. Acetate is a relatively labile form of organic carbon so it is not surprising that the highest $\mathrm{N}_{2} \mathrm{O}$ production rates were in the acetate-amended incubations. However, high concentrations of acetate

Fig. 4. Relation of depth to (a) $\mathrm{N}_{2} \mathrm{O}$ production rate, (b) dissolved nitrate concentration, (c) dissolved organic carbon concentration, and (d) sedimentary organic carbon content. Nitrous oxide production rates are products of incubation with nitrate concentration which correspond to concentrations measured in the field and with no addition of organic carbon. 

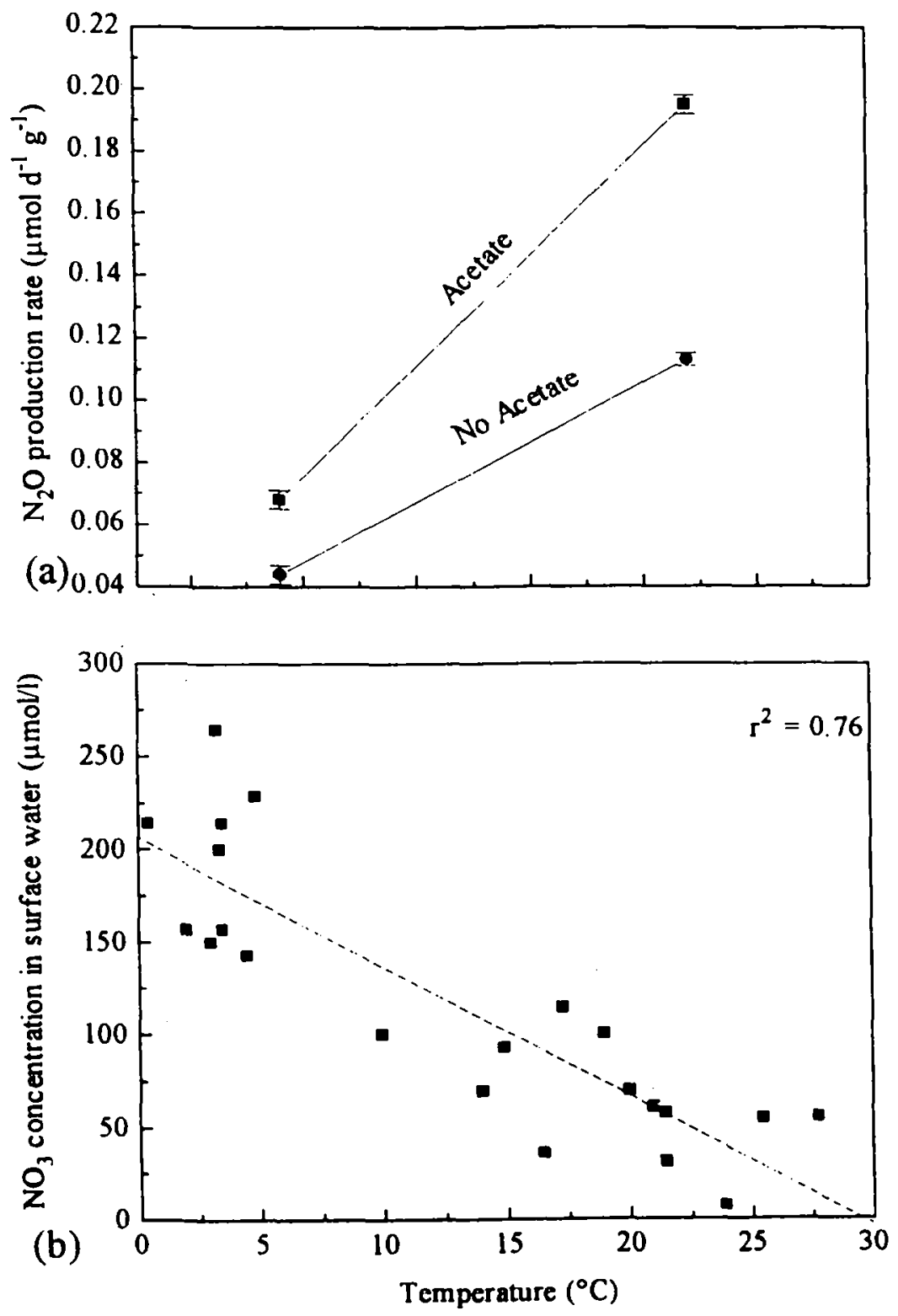

Fig. 6. Relation of water temperature to (a) $\mathrm{N}_{2} \mathrm{O}$ production rate in incubations of medium-grained riverbed sediments using $357 \mu \mathrm{mol} \mathrm{l}^{-1}$ nitrate, and (b) nitrate concentration in the South Platte River at Julesburg, Colorado. Water-quality data from Ugland et al. (1994).

generally were not present in shallow groundwater. The surface-water-derived fulvic acid also supported relatively high $\mathrm{N}_{2} \mathrm{O}$ production compared with the groundwater-derived fulvic acid (Fig. 5). These data indicated that shallow riverbed sediments subjected to mixing with surface water may support higher denitrification rates than the deeper 
riverbed sediments because of the type of organic carbon available as an electron donor.

The $\mathrm{CO}_{2}$ production rates in the incubations also were related to the type of organic carbon in the sediment, but were inversely related to the $\mathrm{N}_{2} \mathrm{O}$ production rates (Fig. 5). The inverse relation between $\mathrm{N}_{2} \mathrm{O}$ and $\mathrm{CO}_{2}$ production rates may indicate that the different organic substrates used in the incubations vary in oxidation state. For example, if organic carbon in the fulvic acids had a higher oxidation state than carbon in acetate, the fulvic acid would require greater carbon tumover per mole of nitrate reduced. Assuming that the $\mathrm{CO}_{2} / \mathrm{N}_{2} \mathrm{O}$ production ratio is a measure of the efficiency by which the different organic substrates supported denitrification, then progressively less efficient denitrification reactions occurred in incubations amended with acetate, surface-water-derived fulvic acid, and groundwater-derived fulvic acid (Fig. 5). The relative efficiency of different types of organic carbon in supporting denitrification may be important in systems where denitrification is organic carbon limited.

\subsection{Effect of temperature on $\mathrm{N}_{2} \mathrm{O}$ production rates}

Rates of $\mathrm{N}_{2} \mathrm{O}$ production decreased by as much as $77 \%$ in sediments incubated at $4^{\circ} \mathrm{C}$ compared with the same sediments incubated at $22^{\circ} \mathrm{C}$ (Fig. $6(\mathrm{a})$ ). These results are consistent with the findings from previous studies indicating that denitrification rates were affected by seasonal temperature patterns (Hanson et al., 1994). An important consequence of these findings is that nitrate concentrations in reaches of the South Platte River dominated by groundwater discharge may increase during the winter when lower temperatures suppress denitrification. Nitrate and temperature data were collected over a 22 month period from the South Platte River at Julesburg, Colorado, a site with sediment similar to the study area. Flow in the South Platte River in the Julesburg area is almost $100 \%$ groundwater return flow. An inverse relation was observed between nitrate and temperature (Fig. 6(b)), indicating that lower temperatures may have suppressed denitrification in sediments along that reach. These results suggest that the chemistry of the river water seems to be at least partly controlled by microbial processes in the riverbed sediments that reduced nitrate concentrations in groundwater before it discharged to the river.

\section{Conclusion}

Denitrification in riverbed sediments is a sink for nitrate in groundwater that discharges to the South Platte River. Laboratory experiments indicated that potential rates of denitrification in the riverbed sediments were limited by the availability of organic carbon and by temperature. Potential denitrification rates were not nitrate limited. Acetate and surface-water-derived fulvic acid supported higher $\mathrm{N}_{2} \mathrm{O}$ production rates than groundwater-derived fulvic acid or sedimentary organic carbon. Potential rates of denitrification measured at $4^{\circ} \mathrm{C}$ were about $77 \%$ lower than rates measured at $22^{\circ} \mathrm{C}$ in the same sediment. Results from this study indicated that high nitrate concentrations in segments of the South Platte River, which are controlled by groundwater discharge, may be due in part to 
denitrification in riverbed sediments that is limited by organic carbon availability. Relatively high nitrate concentrations in the river during winter may indicate that low temperatures seasonally suppress denitrifying activity in riverbed sediments.

\section{Acknowledgements}

This study was funded by the US Geological Survey National Water-Quality Assessment (NAWQA) program, South Platte River Basin Study Unit. We thank Tim Cowdery, Larry Puckett, and reviewers at the journal for their helpful comments on earlier versions of this manuscript.

\section{References}

Aiken, G.R. and Malcolm, R L, 1987. Molecular weight of aquatic fulvic acids by vapor pressure osmometry. Geochim. Cosmochim. Acta, 51: 2177-2184.

Austin, B., 1993. Groundwater monitoring activities South Platte River alluvial aquifer 1992-1993. Report to the Commissioner of Agriculture, Colorado Department of Agriculture.

Bouchard, D.C., Williams, M.K. and Surampalli, R.Y., 1992. Nitrate contamination of groundwater: sources and potential health effects. J. Am. Water Works Assoc., September 1992: 84(9): 85-90.

Bradley, P.M., Aelion, C.M. and Vroblesky, D.A., 1992. Influence of environmental factors on denitrification in sediment contaminated with JP-4 jet fuel. Groundwater, 30: 843-848.

Bradley, P.M., McMahon, P.B. and Chapelle, F.H., 1995. Effects of carbon and nitrate on denitrification in bottom sediments of an effluent-dominated river. Water Resour. Res., 31: 1063-1068.

Fujikawa, J.I. and Hendry, M.J., 1991. Denitrification in clayey till. J. Hydrol., 127: 337-348.

Gold, A.J., DeRagon, W.R., Sullivan, W.M. and Lemunyon, J.L., 1990. Nitrate-nitrogen losses to groundwater from rural and suburban land uses. J. Soil Water Conserv., 45: 305-310.

Hammon, M. and Fustec, E., 1991. Laboratory and field study of an in situ groundwater denitrification reactor. Res. J. Water Pollut. Control Fed., 63: 942-949.

Hanson, G.C., Groffman, P.M. and Gold, A.J., 1994. Denitrification in riparian wetlands receiving high and low groundwater nitrate inputs. J. Environ. Qual., 25: 917-922.

Klemedtsson, L., Svensson, B.H. and Rosswall, T., 1988. A method of selective inhibition to distinguish between nitrification and denitrification as sources of nitrous oxide in soil. Biol. Fertil. Soils, 6: 112-119.

Korom, S.F., 1992., Natural denitrification in the saturated zone: a review. Water Resour. Res., 28: 1657-1668.

Madison, R.J. and Brunett, J.O., 1984. Overview of the occurrences of nitrate in groundwater of the United States. US Geological Survey National Water Summary 1984. US Geological Survey, Denver, CO, pp. 93-105.

McMahon, P.B. and Böhlke, J.K., 1996. Denitrification and mixing in a stream/aquifer system: effects on nitrate loading to surface water. J. Hydrol., 186: 105-128.

Morris, J.T., Whiting, G.J. and Chapelle, F.H., 1988. Potential denitrification rates in deep sediments from the southeastern Coastal Plain. Environ. Sci. Technol., 22: 832-835.

Robson, S.G., 1989. Alluvial bedrock aquifers of the Denver Basin; eastem Colorado's dual ground-water resource. US Geol. Surv. Water-Supply Pap., 2302, $40 \mathrm{pp}$.

Ruddy, B.C., 1984. Streamflow gain-and-loss and suspended-sediment characteristics of the South Platte River and three canals near Fort Morgan, Colorado. US Geol. Surv. Water-Resour. Invest. Rep., 84-4220, 82 pp.

Smith, R.L. and Duff, J.H., 1988. Denitrification in a sand and gravel aquifer. Appl. Environ. Microbiol., 54: 1071-1078.

Smith, R.L., Howes, B.L. and Duff, J.H., 1991. Denitrification in nitrate-contaminated groundwater: occurrence in steep vertical geochemical gradients. Geochim. Cosmochim. Acta, 55: 1815-1825.

Starr, R.C. and Gillham, R.W., 1992. Denitrification and organic-carbon availability in two aquifers. Groundwater, 31: 934-947. 
Ugland, R.C., Cochran, B.J., Hiner, M.M. and Steger, R.D., 1994. Water Resources Data, Colorado, Water Year 1993, Vol. 1. US Geological Survey Water-Data Report No. CO-94-1. US Geological Survey, Denver, $C O$.

Weiss, R.F. and Price, B.A., 1980. Nitrous oxide solubility in water and scawater. Mar. Chem., 8: 347-359.

Wylie, B.K., Wagner, D.G., Hoffer, R.M., Maxwell, S. and Shaffer, M.J., 1993. Spatial distribution of nitrate leaching 'hot spots' and nitrate contributions to the South Platte River Basin aquifers. Rep. 181, Colorado Water Resources Research Institute, Fort Collins, CO, 12 pp. 